\title{
Kadının İmkânsız Tamlığı Olarak Annelik: Reklamlarda Anneler
}

\section{Semiray YÜCEBAȘ ${ }^{1}$}

\begin{abstract}
Öz
Annelik toplumsal olarak inşa edilen bir kadınlık halidir. Ancak çoğunlukla kadına ilişkin bir doğallık olarak kabul edilir. Toplumsal kabullere göre annelik kadının kendisini tam olarak kadın hissetmesini sağlar. Ancak bu his/duygu hiçbir zaman tam olarak telafi edilemez. Reklamlar da bu duyguyu metalarına aktarırlar. Reklamlarda annelik imgesi hem kadının kendisini tam hissetmesini sağlayacak metaları sunar hem de kadına yönelik egemen toplumsal kodları yeniden üretir. Buradaki çalışmada da kadının doğal olarak anne olduğuna işaret eden reklamlar aracılığıyla toplumsal annelik kodları eleştirel kuramsal bir perspektif ve göstergebilim yöntemi ile analiz edilmeye çalışılmaktadır.
\end{abstract}

Anahtar Kelimeler: Annelik, Reklam, Göstergebilim.

\begin{abstract}
Maternity is a socially constructed womanhood. However, it is often regarded as a kind of normalcy related to woman. According to social agreement, maternity ensures that woman feels completely female. But this feeling can never be fully compensated. In advertisements, image of motherhood provides the commodity for woman to make her feel complete, and reproduces the hegemonic social codes for the woman as well. In this study, the aim is to analyse from a critical theoretical perspective and in line with the semiotics the social motherhood codes through advertisements indicating that the woman is naturally a mother.
\end{abstract}

Keywords: Motherhood, Advertisement, Semiology.

Atıf: Yücebaș, S. (2019). Kadının imkânsız tamlığı olarak annelik: Reklamlarda anneler. Akdeniz Üniversitesi İletișim Fakültesi Dergisi, Haziran (31), s. 577-600

1 Dr. Öğretim Üyesi, Gaziantep Üniversitesi İletişim Fakültesi, semirayyucebas@gmail.com, ORCID Numarası: 0000-0002-7314-8028. 


\section{Giriș}

A nnelik mefhumunu kurumsal bir toplumsal anlığın yani ailenin temel yapı taşı olarak görmeye alışmışızdır. Annelik bu birliğin teminatıdır ama erkeğin (babanın) tesis ettiği bir alan veya mekan (uzam) düzleminde bu rolü gerçekleştirebilir. Yani annelik bir bütünlüğün (burada aile) gerekliliği veya teminatı gibi algılanırken hep bir eksikliğin mekanı olarak da cisimleşir-aileyi kuran temel teminat kendisi değildir, nitekim baba evin reisi olmaya devam eder. Annenin toplumsal varlığının bu çelişik içeriği başka bağlamlarda da devam eder. Annelik genellikle sıradan günlük yaşamın pratiklerinde kadınlığın en olgun hali olarak kabul görür, sanki kadınlık annelik ile tamamlanmalıdır. Yani kadının eksikliğini tamamlayan, bütünleyen nitelik onun anne olmasıdır. Burada tümleyen anne'dir. Ancak bu sefer de kadınlıktan ya da üretim iliş̧ilerindeki temel bazı rollerden veya fırsatlardan feragat edilmiştir; yani kadınlığı tümlemeye çalışırken, yine eksilmiştir. Kadınlığın bu tamamlanamamış serüveni çocuğa aktarılmış olarak karşımıza çıkmaktadır. Annelik günümüzde çocukla kurulan bağın mistik, doğaüstü bir nitelik taşımasıyla tanımlanır/bilinir hale gelmiştir. Anne/kadın çocuğu ile kurulan bu üstün bağla tümel bir niteliğe haiz olmaktadır.

Buradaki çalışmada da söz konusu temel ikilikler (eksik-bütünlük) bağlamında annelik hallerinin popüler kültür içerisinde nasıl üretilmiş olduğunu incelenmektedir. Çalışmada annelik hakkında üretilmiş toplumsal anlamlar ve bunların ideolojik içerikleri tanımlanmaya çalışılmaktadır. Nitekim anneliğe ilişkin söylemler içerisinde en belirgin olanı patriarkal düzenin sürekliliğini savunan "kutsal annelik ideolojisi" dir. (Hançer, 2018, s. 188) Ancak buradaki çalışmada annelik salt ideolojik bir süreç olarak değil, ideoloji tarafından farklı söylemsel boyutlarda yeniden üretilen, işgal edilen, eklenen bir esnek tanımlama içerisinde konumlandırılmaktadır. Anne olmanın kadına yüklenmiş bir doğallık işlevi ile tanımlanmış olması bu dizgenin en belirgin niteliğidir. Söz konusu 'doğal'ığın farklı toplumsal bağlam ve anlarda üretilmiş olduğunu, anneliğin kadın için bir öznel tanımlama ve hatta bu süreçlerle toplumsal bir özne haline gelme işlevi yüklendiğini söylememiz mümkün görünmektedir. Bu toplumsal bağlam ve anlardan biri de medya metinleridir. Yaklaşımımız açısından medya metinlerinin diğer başka toplumsal durumlar için olduğu kadar, annelik tanımlamasında da basit ve tek başına belirleyici rol üstlendiğini söylemek zordur. Ancak medyanın toplumsal yaşam kabullerine ilişkin içerikleri dolaşıma sokarak yeniden ürettiğini ve bu bağlamda kadın için bir özne olma anı olarak tesis edilmiş anneliğin de bunlardan biri olduğunu ifade etmek mümkündür. Öte yandan bu süreçte anneliğin toplumsallık içerisinde farklı bağlamlarda üretilmekte olduğunu ve bunlarla kurulan temas sonucunda kadının medya metinlerindeki annelik kurgusu ile yüzleştiğini ayrıca bunun tek yönlü bir etkileşim olmadığını da vurgulamak gerekmektedir.

Yoğun bir gösterge sistemini içermesi nedeniyle reklamlara odaklanan bir anlam teşhisine girişmek toplumsal alanda üretilmiş kodların içeriklerini teşhis etmede faydalı olabilecektir. Reklamların annelik kodlarını dayattığını veya bu tür bir medya metninin izleyiciler üzerinde doğrudan ve basit bir etki düzeneği kurduğunu iddia etmesek de toplumsal kabulleri dolaşıma sokarak kârı maksimize etme çabasında olan bir etkinliğin 
(reklamın), bu başat kabulleri simgesel düzeye taşımaya en fazla heves duyan araç olduğunu da kabul etmek gerekmektedir.

\section{Anneliğin ‘Doğal’ Günlük Yükleri Ve Anneliğin Estetikleșme Serüveni}

Annelik kadınlığı gerçekleştirmenin ya da gerçek anlamda bir kadın olmanın en önemli aşaması olarak görülmektedir. "Küçük yaştan beri kadınlığı annelikle özdeş görecek biçimde yetiştirilmiş kadınlar için anne olmak çok önemli bir statü değişikliğidir. Bu kadının 'gerçek' bir kadın statüsüne yükselmesini sağlayan evlilikten bile önemlidir. Kadın artık hayatın 'gerçek' amacına ulaşmıştır' (Gittins, 2011, s. 121). Kadın anne olmadığı sürece eksiklidir. Bu doğrultuda Freud'da annelik ve fahişelik arasında kurulan bir ilişkinin izleri sürülebilir. Çocuk cinsellik bilgisine sahip olduktan sonra annenin cinselliğini bir sadakatsizlik olarak tanımlar. Fantezilerinin kaynağını da bu sadakatsizlik oluşturur. Erkeğin kadınla kurduğu cinsel arzunun kayağı buradan şekillenir ve kadının (yosmaya benzeyen, sadakatsiz) kurtarılması, ahlakının ve erdeminin sağlanması yani anneleşmesi erkeğin sorumluluğuna girer (Freud, 2016, s. 246-247). Anneye bir hayat bahşetmiş olmasından dolayı duyulan sevgi ona kendi gibi bir çocuk vermekle karşılanır. Böylece kendi kendisinin babası olması arzusunda doyum bulur (Freud, 2016, s. 248). Dolayısıyla kadınlık bir eksiklik olarak kabul edildikçe tamamlayıcılığı annelik olacaktır.

Annelik tarihsel süreç ve toplumsal konumlara göre değişen içeriklere sahiptir. Ancak ortak bir yöne de sahiptir bunlar. Annelik, çoğunlukla kelimenin her anlamıyla yüklü olmayı içermektedir. Üstelik bu yükler günümüzde estetize edilmiş durumdadırlar. "Aile ideolojisinin vurgusu, anneliğin sıkıntısının yüceltilmesinden (çekilen acının çocuğu ne kadar değerli kıldığı vb.), anne bakımının bir toplumsal edim olarak kutlamasına kaymıştır" (Mitchell, 2006, s. 67). Dolayısıyla annelik tarihsel olarak farklı içeriklere sahip olsa da sürekli olarak bir şeyleri yüklenmeyi içerir gibi görünmektedir. Anneliğin hangi içeriklerle yüklü olduğunu betimlemek ise çok boyutlu bir perspektifi benimsemek anlamına gelmektedir.

Öncelikle annelik rolünün toplumsal ve tarihsel biçimlenişlerinin bulunduğunu ve bu biçimlere ait kimi özelliklerin içerilerek kimilerinin ise dışarıda bırakılarak günümüzde yeniden üretildiğini söylemek mümkündür. Günümüzde annelik, koruma ve fedakârlık gibi sıfatlarla ifade edilir:

Gerek toplumsal cinsiyet rolleri gerekse kalıp yargılar doğuştan bireye içkin değildir; ancak toplumsallaşma süreciyle cinsiyetlere özgü normal nitelikler olarak gelenekselleştirilmiştir. Bu noktada annelik durumuna da kadının doğurganlık potansiyelinden hareketle merhamet, fedakarlık, güven, sadakat, koruma ve adanmışlık gibi bir dizi toplumsal cinsiyete ilişkin rol ve kalıp yargılar atfedilerek kadının anne olmasının yüceltildiği ve aksinin 'sorun' ifade ettiği bir toplumsal çerçeve kazandırımaktadır (Bal, 2014, s. 64).

Ancak annelik tarihsel süreçte her zaman böyle tanımlanmış değildir (nitekim bu durum - tarihsellik - annelik hakkındaki fikir ve tahayyüllerin doğalığına yönelik inancı 
da geride bırakmayı gerektirir). Örneğin modern sanayi kapitalizmi öncesi dönemde kadının temel görevleri ev içi işlerle ilgilenmek ve üretim süreçlerindeki kimi rolleri yerine getirmekti. Bazı sınıfsal farkılıkları göz önünde bulundurmak kaydıyla, erkeği cinsel anlamda memnun etmeyi de bu görevler arasına koyabiliriz. Doğum yaptıktan sonra emzirme süreci uzadığı için bu 'görevi' yerine getiremeyen kadın, çocuğu sütanneye devrediyordu. Dolayısıyla kadının asıl görevi günümüzde anlaşıldığı biçimiyle bir anne olmak değildi. Çocuk sahibi olmak ya da doğurganlık, kadın için önemli bir toplumsal kabul mekanizması işlevine sahip olsa da çocuğa yönelik fedakârlığı içeren ve çocukmerkezli bir yaşam biçimine işaret eden bildik annelik mefhumu ile karşılaşmak pek de olası değildi². Bu evrede çocukluk kısa bir süreç olarak deneyimleniyor, yetişkinlik ile çocukluk arasındaki ayrım muğlaklığını koruyordu. Ayrıca çocuğun kötü ve şeytani özellikleri barındırdığını içeren kimi toplumsal pratiklere bile rastlamak olasıydı (Gittins, 2011 , s. 61-62). Bu nedenle anne ile çocuk arasında günümüz annelik pratiğini ifade etmemizi olanaklı kılacak o özgül bağları görmek pek de mümkün değildi.

Sanayi devrimi, annelik pratiklerinde bazı dönüşümlerin yaşanmasına neden oluyordu. Anne olmak bu evrede de kadının temel sorumluluğuydu, çalışmak zorunda olsa da bu işler asıl kadınlık vasfının (annelik) yanında ikincil nitelikteydiler. Bu dönemde orta sınıf ya da burjuva ailelerde erkek otoritesi çocuklar üzerinde de hissedilirken, işçi sınıfı ailelerinde çocukların sorumluluğu diğer kadınlarla birlikte annenin kendisindeydi (Gittins, 2011, s. 123-124). Aile bu evrede küçülüyor, çocuklar geleceğin teminatı olarak da görünen kimi sorumluluklarla tanımlanıyordu. Ancak günümüz estetikleştirilmiş annelik mefhumlarının kimi nitelikleri modern kapitalizm ile birlikte şekillenmeye başlamıştı. Orta sınıf aile olarak tanımlanacak bu yeni aile biriminde kadının annelik rolü farklı bir içerik kazanıyor hatta annelik hakkında doğal görülen kimi nitelikler bu süreçte şekilleniyordu. Anne ile çocuk arasındaki ilişki, sosyo-ekonomik dönüşümle birlikte farklılaşmaya başlıyordu. Söz konusu bu dönüşümlerin sonucunda çocukluk süresinin uzaması ${ }^{3}$, çekirdek aileye geçiş, toplumsal ancak çoğunlukla doğallıkla karşılanan ev içi çalışmanın kadına aktarılması karşımıza çıkmaktadır. Sonuçta kadın, “ev içinde giderek duygusal yaşamın merkezine yerleşen bir 'eş-anne' olma işlevi ile donatılmıştır. 'Anneliğin icadı' olarak adlandırılan gelişmenin sosyal arka planında böyle bir süreç yatmaktadır” (Aytaç, 2007, s. 89). Bu süreçte çocuklar duygusal bakımın merkezine yerleşmeye başlamaktadır. Bunun arkasında yeni çağla birlikte çocuğun gelecek için bir teminat oluşturacağı fikri de yatıyordu kuşkusuz .1980 sonrası dönemi

2 "Çocuk bakımının kadınların işi olduğu varsayımı evrensel olmamakla birlikte oldukça yaygındı ve sanayi öncesi Avrupa`sında kesinlikle geçerliydi. Ancak bu işi üstlenenin anne olduğu anlamına gelmiyordu. - Anne emeğini bira yapımı gibi daha önemli işlerde kullanırdı. Birçok anne çocuklarının bakımını üstlenmişse de bu iş sık sıkta hizmetkarlar, kız çocuklar, diğer kadın akrabalar veya komşular tarafından yapılırdı" (Gittins, 2011, s. 29-30). Türkiye'de de modernleşme süreçleri bağlamında benzer süreçleri görmek mümkün olabilir. Keskin bir ayrım olmadan iki türlü annelik pratiklerini aynı zaman dilimleri içersinde gözlemleyebiliriz.

3 "Eskiden 7 veya 8 yaşında sona erdiği düşünülen çocukluk ve bağımlılık döneminin süresi de ergenlik çağına kadar uzatıldı. Bunlar yeni aile ideolojisine bağlı orta sınıfın görüşleriydi, ancak XIX. Yüzyılında çocukların çalışmasını engelleyen ve eğitimi zorunlu kılan kanunların yürürlüğe girmeye başlamasıyla etkileri topluma yayıldı" (Gittins, 2011, s.66).

4 "Aydınlanma fikrinin temel kurucu öğelerinden birinin ilerleme inancı olduğu sık sık vurgulandı. İlerleme, bugünün geçmişten daha iyi olduğu ve geleceğin de bugünden daha iyi olacağı, zorunlu bir tarihsel gelişim çizgisi bulunduğu anlamına gelmektedir. Konumuz açısından bakınca tarihsel ilerleme inancı, bizim yaşantımızın atalarımızınkinden daha iyi olduğunu, gelecek kuşakların yaşamlarının da bizimkinden zorunlu olarak daha iyi 
bu sürecin görünür olduğu bir dönem olarak tanımlamak mümkündür:

Ben'e en çok vurgunun yapıldığı, 'kendin ol', 'kendini sev', 'mutlu et kendini' vb telkinlerle 1980 sonrası dönem, aynı zamanda çocuğun psikolojik Küresel Kültürel Değişim ve 'Yeni' Annelik: Ankara Kamil Ocak Mahallesi Örneği 56 değerinin öne çıktığı, çocuk bakımı ve çocukla iletişim konularında bilgi/ enformasyon üretiminin yoğunlaştığı bir dönemdir (Işık, 2015, s. 55-56).

Şefkat, özen, bakım ve özveri modern anneyi tanımlayan nitelikler haline gelmişti. "Bu yeni annelik sevgisi şeklinin kadınlar için doğal olduğu düşünüldü... Bunun ötesinde, kendileriyle çocukları arasında öyle derin bir bağ yaratmaya teşvik edildiler. Bu suretle, daha önce görülmemiş bir şekilde burjuva kadınları yaşamlarının önemli bir bölümünde eve kapatılılar" (Poster, 1989, s. 200). Bu, orta sınıf ailelerde kadının sosyal ve ekonomik gelişmelerin dışında konumlanmasına neden oluyordu. Ayrıca çocuk ve ev/yuva bakımına yönelik söz konusu bu lütufkâr uygulamalar yanında yeni kaygı (anxiety) ve gerilim kaynakları da getirdi ve çocuğun başına gelen herhangi bir şey annenin hatası olarak düşünüldü (Poster, 1989, s. 202).

Öte yandan üretim süreçlerine katılmak zorunda olan kadınlar için de yaşam farklı düzlemlerde aksa da toplumsal cinsiyet rolleri benzer içeriklere sahipti. Çalışıyor olmak kadını ev içi işlerden, çocuk bakımından ve annelikten uzaklaştırmıyordu. "Ücretli işçiliğin gelişimi ve ev ile işin gittikçe ayrılması kadınları eskisinden daha istikrarsız iki pazarın insafına terk etmişti. Evlilik pazarı ve emek pazarı. Her iki piyasada da durumları kötüydü ve kadın her ikisine birden girse bile ekonomik koşulları tehlikedeydi” (Gittins, 2011, s. 43). Dolayısıyla ev ve işyeri, kadınlık halleri ile anneliğin devam ettiği ve yeniden üretildiği mecralardı. Kadına yakıştırılan meslekler de annelik rolü ile biçimleniyordu. Örneğin öğretmenlik, hemşirelik, sekreterlik gibi. Söz konusu bu mesleklerin her biri biriyle ilgilenmek, birine bakmakla ilintilidir. "Sekreterlerden patronlarına kahve yapmaları, onların taksilerini çağırmaları, sosyal etkinliklerini düzenlemeleri, eş ve çocuklarına vereceği hediyeleri almaları kısaca onlar için çalışmakla kalmayıp onlara 'bakmaları' beklenir. İlkokullarda küçük sınıfların öğretmenleri her zaman kadınlardır. Kadın polis memurlarına genellikle başkalarına bakmayı gerektiren işler verilir" (Gittins, 2011, s. 133). Dolayısıyla kadının kapitalist üretim süreçlerine katılma deneyimi de çoğunlukla anneliği çağrıştıran içeriklerle şekillenmektedir. Ancak bu annelik kodunun da tarihsel olduğunu unutmamak gerekiyor. Bu annelik kodu, günümüzde estetize edilmiş durumdadır. Artık kadınlık rolleri dışarıda olmak, özgürlük ve bağımsızlıkla estetize edilirken, diğer yandan da bilindik kodlarda bu alanın içerisinde yeniden üretilmeye devam etmektedir. Bu nedenle estetik kadınlık kodları, zaman zaman modernizmin şefkatli, kendini adamış annesiyle de çelişir gibi görünür.

Yeni kapitalizm, "her şey senin için", "sen her şeyi hak ediyorsun" gibi mottolarla bireye seslenir. Gel gör ki anne olmak, bu durumu tersine çeviren bir duruma tekabül eder. Zira annelik artık "kendini unutmak", "kendinden başkasını daha fazla düşünmek" ve "kendin olmaktan” vazgeçmekle neredeyse birebir aynıdır. " 'Önce ben’in ilke haline geldiği bir uygarlıkta annelik bir meydan okuma, hatta bir çelişkidir. Anne olmayan 
bir kadın için meşru olan şey, çocuk ortaya çıktığında meşruiyetini yitirir. Kendine ilişkin kaygılar yerini kendini unutmaya bırakır ve 'her şeyi istiyorum' şiarı 'ona her şeyi sunmalıyım'a dönüşür" (Badinter, 2015, s. 21). Yeni kapitalizmi orta sınıfına ait bu ideoloji, anne-çocuk ilişkisinde ve daha çok da anneliğin tanımlanışında kendini ifşa eder. Annelik, tüm özveri ve kendini yok etmelerle çocuklara veya aileye dünyayı ayakları altına sermekle betimlenir. Anneliğin estetizasyon süreci de bu şekilde tamamlanmış olur. Modern üretim süreçleri bağlamında şefkatli ve geleceği düşünen anne imgesi artık estetik bir imge haline gelmiştir. Dolayısıyla günümüz annesi çok katmanlı, emek ve simgesellik arasında salınan bir karaktere sahiptir:

"Modern anne, çocuklarına modern tıp ve çocuk uzmanlarının sunduğu "en gelişmiş" bilgilere uygun bir bakım vermeli, bu esnada onları çağın fikirlerine göre yetiştirmeli ve bilişsel gelişimlerini desteklemelidir; tüm bunları yaparken de sosyal hayatını ve mümkünse kariyerini devam ettirmeli, kişisel bakımını da inmal etmemelidir" (Sever, 2015, s.74).

Kadının bir yükümlülük, iş bölümünün sonucu ve yaşamın tek tercih edilebilir yolu olarak gördüğü annelik, estetik olarak arzu duyulan, içten gelerek tercih edilen kadınlık hallerinin başında gelmektedir.

\section{Anneliğin politik yükleri}

Anneliğin kadına yüklenen ev içi rollerine ek olarak ve hatta bunlardan türetilmiş ya da tüm bunları yeniden üreten politik içerikleri çağrıştıracak şekilde toplumsal hayatta yer edindiğini söylememiz mümkündür. Dolayısıyla annelik politik olarak da yüklü bir kavramdır. Öncelikle annenin birlikte alındığı toplumsal alan olarak aile kamusal alanın dışında kalan bir mecra olarak konumlanır. Ancak bu ayrımın kendisi politik bir içeriğe sahiptir: "Aile, yani kadın ve çocukların doğal yaşam alanı 'apolitik' varsayılıyor yani içinde güç ve iktidar ilişkilerinin değil, insanların doğal duygusal ilişkilerinin yaşandığı düşünülüyor. Bu, modernlik ideolojisinin apolitik aile/politik kamu ayrımıdır ve modern iktidar ilişkilerinin en temel düzenleme stratejilerinden biridir" (Sancar, 2012, s. 197). Dolayısıyla annelik de ailenin asli unsuru ve yapıcısı olarak iktidar stratejilerinin üzerinde gezindiği bir mecradır.

Günümüz toplumsallığında kadının anne olabilme yetisine vurgu yapılmaktadır. $\mathrm{Bu}$ vurgu, egemen siyasal ideolojiye içkindir. Kadının ev/yuva içindeki tasvirinin (annelik), gündelik hayattaki söylemlerden tutun da ders kitaplarına kadar sirayet ettiğini görmekteyiz. Kadının temel sorumlulukları arasında görülen ev/yuva kurma ve kurulan bu evin/yuvanın devamından, gelişiminden sorumlu olma kadının var olma nedenini oluşturur. Dişi kuşun evi/yuvayı çekip çevirmesi ile başlayan kimi ideolojik anlamlandırmalar aynı zamanda içinde bir siyasal ideolojinin kurulumunu da taşır. Bu tür nitelikleri ile aile politik alana bir gösteren olarak taşındığında - zaten ancak bu haliyle taşınabilir (yani ortalama çekirdek aile olarak) - kendine has toplumsal içerikleri ile kendinin ve toplumun yeniden üretiminin önemli bir parçası haline gelir. Örneğin aile milletin yeniden üretimini sağlayan bir gösterene dönüşür. Bu aynı zamanda kadınların üreme nosyonunu yani kadınlığın toplumsal olarak kurgulanmış 'doğal' niteliğini 
yeniden üreten bir işlevselliğe sahiptir. Yani doğurma, artık birincil anlamından daha da fazlasını içerecek şekilde toplumsallaşır. Ama bu başka alana geçiş aynı zamanda ona mitik bir değer de katacaktır ki ancak bu şekilde toplumun en doğal gördüğü insan etkinliğine dönüşebilir. Doğurmak, kadınlığın en doğal sorumluluğu olma niteliğini ulusal bir görev olma fikri ile kazanır: "Milliyetçi düşünce heteroseksüel bakış açısıyla kadınları biyolojik üreticiler konumuna indirger ve çocuk doğurma kapasitesi ile tanımlar. Ulusun biyolojik olarak inşası da bu bağlamda kadınların görevi olarak tanımlanabilir. Doğrulan çocukların bakımı ve eğitilmesi de bu anlamda ulusal bir görev olarak kadınlardan beklenir" (Sancar, 2012, s. 57). Kadın sadece çocuk doğurmakla milletine ve vatanına hizmetini bitirmez. Anne olmanın yanı sıra yeni nesillerin eğitiminden de ilk olarak anneler sorumludur. "Yine de kadınlar milletin sadece biyolojik yeniden üreticileri olmayıp, aynı zamanda da kültürü çocuklara iletmekten veya ‘yuva’yı özgül bir kültürel biçimde kurmaktan sorumlu 'kültür' muhafızları olma görevi verilmiş, milletin kültürel yeniden üreticileridir" (Yuval-Davis, 2003, s. 214). Milli kültürü yeni nesle aktaran ilk kişi annelerdir. Milli olarak kutsallıkları da buradan gelir. Anneler aynı zamanda yeni nesle örf/adet/gelenek ve kültürü de aktararak toplumun gelecekteki sağlıklılığından da sorumlu tutulurlar. Diğer bir deyişle eksikliğin telafi edicisi olarak yani bireyin yurttaşa ve oradan da devleti ile bütünleşmiş bir millete varışı için mutlak eksiklik sağaltıcısı anneye işaret edilir. Vatan ve annelik arasında kurulan bağlantının kaynakları burada gizli gibidir. Annelik, ancak hiçbir zaman da tamamlanamayacaktır; o, ulusal birliğin tesisinin her gün yeniden işe başlayan medyanın süreklilik arz eden bir işi olması gibi durmadan kendini yenilemek durumundadır.

Eğer bir kadın çalışmak zorunda kalıyorsa yapacağı işlerin, anne olma niteliğinden üretildiğini daha önce vurgulamıştık. Örneğin öğretmenlik, hemşirelik gibi meslekler kadının fıtratına, anneliğine uygun mesleklerdi. Bu tür mesleklerin aynı zamanda yeni nesillerle veya toplumun (milletin/ulusun) bakımı ile ilgili işler olduğuna da işaret etmek gerekiyor. Öğretmen yeni nesile millet olabilme bilincini aktaran kişidir. Anneden alınan ilk eğitimden sonra çocuk, yeni neslin üyesi olmak üzere öğretmene devredilir. Ayrıca öğretmen şefkatli, merhametli ve yumuşak huylu olmalıdır ki yeni nesli sabrı ile yetiştirip, onları bilinçli bireyler haline getirebilsin. Bu özellikler de en çok kadında ve tabi ki anne olan kadında bulunur. Türkiye özelinde düşünüldüğünde de modernleşme sürecinde kadına benzer bir anlamın ithaf edilmiş olduğunu da görmemiz mümkün:

Kadınlardan beklenen modern aileler, evler, çocuklar ve modern bir gündelik yaşam inşa ederek modern bir toplum kurma sürecine- erkeklerin yanı sıra ve onlardan farklı biçimlerde- katılmaları. Türk modernleşmesinin öncü kadınları toplumun aileden ve annelikten başlayarak inşasının mimarları olmuşlar. Buna bağlı olarak da, annelik ve ev kadınlığı ile bağdaşacak, örneğin öğretmenlik, hastabakıcılık, ebelik gibi mesleklerde eğitilmeleri bir devlet politikası olarak desteklenmiş (Sancar, 2012, s. 192).

Öte yandan kadın, sadece toplumsal sorumluluğu ile değil, bir "ev"in bakımıyla da sorumlu görülür. Bu ev, aynı zamanda toplumsal alanda farklı içeriklere sahip olmakla da anlamlı bir yere taşınır. Kadının sorumlu olduğu ev, milliyetçi ideolojilerde kutsal bir yere sahiptir. "Bütün milliyetçi hareketler, evi bir metafor olarak kullanır. Bununla da kalmaz, bir ev ideali hepsinde vardır. Hem bir evin nasıl olması gerektiğini, hem 
de evin toplumsal düzen içinde nasıl bir işlevi olacağını konu eder milliyetçi yazarlar. Milliyetçiliğin ve milletin sembolleri, metaforları 'bağır' gibi, 'ana-vatan' gibi, 'ana-yurt' gibi, doğrudan doğruya o ilk 'ev’le ilişkilidir” (Bora, 2013, s. 68). Dolayısıyla kadının bu evle yakından bir ilgisi bulunacaktır. Anneliğin vasıfları da bu süreçlerle bağlantılı bir şekilde çizilmiştir.

Cumhuriyet modernleşmesinin ilk fazı, kimin makbul, kimin makbul olmayan anne olduğu arayışıyla geçmiş, yeni kurulan ulus devletin temeli aileye ve ailenin en önemli üyesi ilan edilen anne-kadına dayandırılmıştır. Makbul anne ve anneliğin sınırları ise net biçimde çizilmiştir; doğurgan, bakımlı ancak ölçülü, neşeli ve bedenen sağlam, çocuklarını sorumlu annelik ve ulus bilinciyle eğitebilen, görev bilinciyle hareket eden anne vatandaş (Demirci-Yılmaz, 2015, s. 89).

Kadının buradaki ev içi konumunun yine de belli ölçülerde erkekle eşit bir statüde kurgulandığını söylemek mümkün.

Kadının aile içindekini konumunu annelik ile tanımlayan ve bunu hiyerarşik bir aile mefhumu ile birleştiren yönelim asıl olarak muhafazakâr ideolojinin mihenk taşını oluşturur. Muhafazakâr ideolojide bir toplumun/topluluğun ya da cemaatin üyesi olmak öncelikli bir varoluş biçimidir (Willettis, 1992, s. 68). Yani birey veya nesnel ilişkilerin ifadesi olarak sınıftan önce topluluğun kendisi muhafazakâr ideolojinin temel birimini oluşturur. Bu topluluğun merkezinde ise aile yer almaktadır.

$\mathrm{Bu}$ siyaset felsefesi aileyi hem toplumun temel birimi hem de geleneksel ahlakın koruyucusu olarak görmektedirler. Çünkü aile toplumu bir arada tutan bağların bir kısmını yaratır ve pekiştirir. Aynı zamanda aile, toplumun atomize olmasını önler, toplum içinde dayanışmayı sağlar ve nihayet temel eğitim kurumlarından biri olma işlevi görür. Aile, insanlardan toplumlarına aidiyet ve ilişkinlik duygularını güçlendirir (Vural, 2007, s. 57).

Ailenin muhafazakâr ideolojide toplumun temeline yerleştirilmesi toplumsal dayanışma ve birliğin de tezahürü olarak yorumlanır. Muhafazakâr ideoloji, aileyi - her ne kadar modernizmle birlikte bu aile değişmiş olsa da - kutsayarak toplumsal alanda kendine somut bir zemin kazandırmış olur. Bu ailenin aynı zamanda otoriter ve normatif bir aile olduğunu da ifade etmek gerekir:

Muhafazakar politika açısından merkeze alınan aile, eşitlikçi dinamiklere açıktan alınan bir karşı tavrın ürünü olan, otoriter ve normatif bir aile nosyonudur. Kadın erkek eşitliğinin sürekli inkarı ve onun yerine kullanılan 'adalet', 'eşdeğerlilik' gibi kavramlar, geleneksel ve eşitsiz ve özcü bir 'tamamlayıcılık' argümanına dayanmaktadır. Kadın ve erkeğin farklı dünyalara, farklı değerlere, farklı yaşamlara sahip olduğuna ilişkin bu özcü argüman, kadınları annelikleri üzerinden tanımlayarak kadın yurttaşlarla 'farklı' bir ilişki kurmaktadır (Öztan, 2015, s. 103).

Türkiye'nin önceleri merkez sağ dinamikleri içerisinde yer alan ancak günümüzde egemen politik ve toplumsal formları temsil eden muhafazakâr ideolojinin aile kurgusunda da kadın hem salt bir anne olarak kurgulanmakta hem de eşitsiz olmayan ilişkilerin içinde yer almaktadır. Burada kadının asli görevi çocuk (hem de çok çocuk) yapmak görülmektedir. Çocukların bakımı, evin düzene sokulması kadının sorumluluğundadır. Bunlar kamusal alanın dışında kalan öznel alanın sürekliliğini de sağlayacaktır. Ancak muhafazakâr ideolojinin temel savları bu özel alandan üretilmiştir. 
Anne ailenin gündelik işleyişinin garantörü olarak en temel toplumsal birlik olan ailenin yani toplumun geleceğinin de teminatıdır.

Dolayısıyla sivil nizamın tesisi kadının ailedeki annelik rollerini yerine getirmesine bağlıdır. Böylece annelik rolü, muhafazakâr tahayyülde toplumsalın varlığını mümkün kılan bir statüye yükselmiştir. Muhafazakâr ideoloji sivil niteliğini (yani toplumda var olduğunu iddia ettiği somut yaşam pratiklerini) devletli düzeye taşıdığında ise sivil alan ile birleşmiş devlet fikrine ulaşmış olacaktır. Böylece kadının annelik statüsü de devletin asli meselelerinden biri haline gelecektir. Bu kurguda kadının, bütünün (ailenin ve milletin) bir parçası olmak dışında varlığı söz konusu olmadığını söylemek mümkündür (Kancı, 2015, s. 87).

Türkiye'de kadının annelik yükleri ile donatılmasının milliyetçi ve muhafazakâr ideolojilerin perspektifine uygun içeriklerini belirli ölçülerde görmemiz mümkün görünmektedir5. Günümüz Türkiye'sinde ayrıca neo-liberal dönüşümlerle kültürel alanın tanımlanma pratiklerini belirleyen kimi etkinlikler de bu yüklerin yeniden üretilmesinde önemli bir rol oynamaktadır. Popüler kültürde sıklıkla kadına yüklenen annelik rolünü yukarıda açıklamaya çalıştığımız yüklerle birlikte görmek mümkündür. Kendimizi toplumsal kabullerin, bunlardan üretilmiş değerlerin, taleplerin ve beklentilerin yoğunlaştırıımış içeriklerle şekillenen reklam öğesi ile sınırlandırdığımızda da benzer sonuçlarla karşılaşmamız olasıdır.

\section{Reklam ve anneler}

Popüler kültür, egemen annelik kodlarının yeniden üretildiği bir mecra olarak karşımıza çıkar. Ancak bunun kolaylıkla kurulan bir ilişki olmadığını ve popüler kültür ürünleri karşısında annelik kodlarının tek bir kaynaktan türetilmiş olmadığını da kabul etmemiz gerekir. Nitekim popüler kültür ürünleri karşısında çoğunlukla pasif izleyiciler konumunda değilizdir. Popüler kültür ürünleri ve tüketiciler arasındaki ilişkiyi izleyicinin aciz, edilgenleştiği, kendine yabancılaştığı, değer yargılarının yok olduğu şeklinde tanımlamak yol gösterici değil (Binark, 2014, s. 246). Ancak popüler kültürü belirli bir toplumsallığın mekanizmaları içerisinde olması nedeniyle özgür bir alımlamanın tüm olanaklarını devreye sokan bir yaklaşıma da intiyatla yaklaşmak gerekiyor ${ }^{6}$. Popüler kültür genellikle endişelerimize, hayallerimize, umutlarımıza işaret eden göstergeler bütünü olarak, hayatın imkânlarını belli bir çerçevede sürdürmemize imkân tanır. "Popüler kültürün bir toplumsal işlevi vardır. Toplumsal gerginlikleri yumuşatır, yatıştırır. Toplumsal sorunlara sunduğu çözüm önerileriyle tüketiciler için rol modeli işlevi görür»

\footnotetext{
5 Gelenek ve modernliği bir arada deneyimliyor olmak yani muhafazakâr bir yaşam kabulü kadına yüklenen toplumsal rollerle de ilgili görünüyor veya en azından toplumsallıkta söz ettiğimiz ideolojinin yaygınlaşmasında bu roller önemli bir etken olabiliyor. Sancar bu durumu şu şekilde izah etmektedir: "Ev idaresine programlanmış modern ev hanımları, erkeklerin yaşam tercihlerinden doğan bütün olası istikrarsızlıklar ve gel-gitler karşısında sabit bir görev ile var oluyorlar ve değişimin değişime uğratamadığı 'hane'nin istikrarını ve geleneksel değerlerin sürekliliğini 'aile' aracılığı ile temsil ediyorlar. Geleneği ve modernliği bir arada temsil eden kadınlar hem modernleşmiş evin içini hem de değişmeyen geleneği temsil ediyor (Sancar, 2012, s. 316).
}

6 Çaylı Rahte'nin (2014) popüler kültüre yönelik intiyatlı yaklaşımların Türkiye'deki karşılıklarını sunduğu çalışması bu tartışmada aydınlatıcı olabilir. 
(Korkmaz ve Yaylagül, 2008, s. 132). Söz konusu işlev annelik konusunda da karşımıza çıkar.

"Popüler kültürü üreten ve bu üretimin merkezinde yer alan medya hem görsel, hem yazılı medya olarak anneliği televizyon programlarında, yazııı basında, sosyal medyada, yani medyanın tüm araçlarında günümüz post modern kodlarına uygun bir biçimde kullanmakta, "aşırı annelik" vurgusuyla tüm kadınları pedagojik eğitimden geçmiş, çocukları hayatının merkezinde ve daha da önemlisi hayatlarının tek unsuru olarak tek tipleştiren bir konumda bulunmaktadır" (Türkdoğan, 2013, s. 46).

Reklamların da temel işlevi bir metayı satışa çıkarmayı ona giydirilmiş bilindik anlamlar aracılığıyla gerçekleştirmektir; yani popüler kültürden. "Reklamlar, olabildiğince yaygın kabulü görebilmek amacıyla, biçimlerini popüler kültürden alırlar" (Rutherford, 2000, s. 93). Bu nedenle bizlere tekil olarak seslenirken, aynı zamanda bizi belirli türde bir toplumsallaşma pratiğine de davet ederler. "Hiç kuşku yok ki reklamcıların satışları yalnızca ürünler, hizmetler ya da soyut fikirler değildir. Onlar ayrıca ürünlerin birbirleriyle etkileşim halindeki imajlarını kuşatan, yorumlayan, tasarlayan bütünsel ve çok katmanlı düşünsel sistemleri de satarlar" (Lull, 2001, s. 24). Bu sistemde kadına yüklenen anlamların da metaya aktarıldığını görmek olasıdır. Reklam kampanyaları, annelik temsilini adeta görünmez bir kılıf olarak üzerinde giymekte ve bu yolla cinsiyet temelinde oluşturulan bir toplumsal cinsiyet vurgusunun kodlarını yeniden üretmektedir (Bal, 2014, s. 64). Kısacası kadın reklamda bilindik imgeleri ile karşımıza çıkar.

“...margarin reklamlarında özenli anne, deterjan reklamlarında titiz ev kadını, banka reklamlarında güler yüzlü memure, modern ev araç gereçlerinde çağdaş iş bilir kadın, motor yağı reklamlarında akıcı, ateşli bir malzeme, araba reklamlarında aracın erkeksi çekiciliğinin büyüsüne kapıımış dişi, kısacası her durumda kullanıma hazır, kendisine her tür anlamın atfedilebileceği esnek bir malzeme olan kadınlar kurgulanan özellikleriyle pazarlanan malı, hizmeti tariflerler" (Sektanber, 2011, s. 201).

Kadın meta kültürü içerisinde, metanın anlam kazanmasını bilindik yolda sağlayan meta benzeri bir niteliğe dönüşür ${ }^{7}$. Toplumsal hayatta kendisine yüklenebilecek her türlü anlam ve değerin taşıyıcısı olarak kadın, modern zamanların kendinde özne niteliğini sürdüremez. Kadının bir önceki toplumsallıktan devşirilmiş araçsallığı modern kapitalizmde de meta için araç olmakla devam ettirilir. Annelik de bu bilindik formlardan biridir. Örneğin:

Reklamlar, kadın dergileri, gazeteler, ekonomi sayfaları, insan kaynakları ekleri, erkek dergileri, filmler, diziler, hırsı, ideal kadını çizerken, kimi zaman yanına bir bebek figürü koymayı da inmal etmemektedirler. Egemen ideoloji kitle iletişim araçları aracılığı ile kadınlar için biçilen rolü tekrarlamakta kadınlar da bu rolleri içselleştirmekte, sosyal yapılandırma olduğunun farkına varmaksızın kabullenmektedirler (Uğurlu, 2013, s. 8-9).

Reklamlarda kadının kutsallığı annelik dolayımı ile inşa edilir. Ancak annelik durağan sabit bir kimlik temaşası da değildir reklamlarda. Aynı zamanda bir deneyimdir. Zira günümüzde başarılı reklamlar günümüzde yaşam dünyalarını ve yaşam tarzlarını kurgulayarak ürünlerin bu yaşam dünyalarının bir parçası oldukları izlenimini

7 Modleski (1998, s. 39), içinde yaşadığımız toplumda kadınların hayatın tarihin dışındaymış gibi görünen yanını temsil ettiğine işaret eder. Bu nedenle boş zaman etkinliklerini dolduran kitle kültürünün arenası kadınlardır. 
uyandırmaktadır (Funk, 2007, s. 33). Bu nedenle reklamlardaki anne imgesi aynı zamanda toplumsal olarak üretilmiş anneliği deneyimliyor olmanın izleklerini sunmaktadırlar.

Reklamlar toplumsal ve tarihsel değer yargılarının ve kabullerin doğallaştığı mecralar olarak karşımıza çıkmaktadır. Reklamlar toplumsal alanın mitlerini inşa eden kültürel ürünler olarak görülebilir. Annelik imgelerinin de reklamlarda anneliğe ilişkin toplumsal kurguları doğallaştıran birer mit olarak işlev gördüğünü söylemek mümkündür.

"Reklam metinleri içerisinde yer alan annelik kurgusunun oluşturulma biçimi çok boyutlu bir sürece işaret etmektedir. Söz konusu metinlerdeki annelik miti, ataerkil sistem içerisinde toplumsal yaşamda karşılı̆̆ı bulunan değerlerle ilişkilendirilerek konumlandırımakta, aynı zamanda sürekli olarak benzer metaforların kullanımıyla benzer anlamların üretildiği cinsiyetlendirilmiş emek süreçlerin, toplumsal rol ve sorumlulukların doğallaştırımış ayrıştırıcı niteliğini, kamusal ve özel olarak isimlendirilen alanlardaki ayrımı meşrulaştıran bir anlam bütününü inşa etmektedir" (Bal, 2014, s. 63).

Anne, reklamlarda da belirli mekânlar içerisinde (mutfak, ev gibi) görünürlük kazanmakta, özel alana sıkıştırılmış toplumsal sorumluluğu ile ataerkil formlarla uyum içinde sunulmaktadır. Doğal annelik kodları reklamların ışıltılı dünyasından oturma odalarına süzülmekte, oradaki kabullerle de örtüşerek kadına yönelik bütünlüğü tesis edebilmektedir.

Reklamlar kadınlara annelik formları üzerinden yine eksiklikleri ile seslenmektedir. Reklamlar birer çağrı (isimlendirme) metinleri olsalar da özneyi hiç bir zaman kendi içinde tam bir bütünlük olarak kurmazlar. Eksikliğe işaret edilir ki daha sonra bu eksiklik reklam tarafından tanıtımı yapılan meta ile doldurulabilsin. Annelik ilk etapta kadının tamlık talebine işaret eden bir sağaltıcı rolü yüklenir ama yine de henüz her şey tam olarak yerine oturmamıştır. Evde ya bir temizlik sorunu vardır, ya beslenme ya da çocukların bakımı... Bunların ortadan kaldırılması anneliği eksik hissetme duyusundan kurtaracaktır. Bu noktada devreye bir deterjan, bir sabun, bir margarin girecek ve onlar sayesinde annelik olması beklenen, istenen yere varmış olacaktır. Bir margarin veya sabun anneliğin olunması beklenen yere taşınmasını sağlayacak ama beklenen yer (genellikle izleyici tarafından ulaşılacak olandır da) zaten yanı başımızda evimizin gündeliğinde olandan da başka bir şey olmayacaktır. Temizlik yapan, çocuk bakan evi evirip çeviren anne zaten bunları yaparken şimdi daha iyi yapacaktır. Anne olmayı bir mücevher, bir mutfak aleti ya da çocukların yediği yemekten sonra ona dönen sıcak bakışları ile tekrar tekrar hissedecektir.

Dolayısıyla reklamlarda işlenen kadınlık imgelerinden biri olan "annelik" kadının doğal hallerinden biri olarak karşımıza çıkmaktadır. Reklamların doğal olan ile kurdukları ilişki çoğunlukla üretilmiş bir doğallığa karşılık gelmektedir. Doğal olan aslında birçok işlem görmüş olmaktan sonra ulaşılan bir sonuçtur. Kadının doğal hali olarak annelik de biyolojik bir modun (çocuk doğurmak) toplumsal işlemlerden geçmesinden başka bir şey değildir. Kadın reklam evreninde toplumsal kabullere uygun olacak şekilde doğallığına kremler, şampuanlar, sabunlar ve temizlik malzemeleri kadar annelikle de ulaşmaktadır. Çoğunlukla doğalık kazandıran metaların (dezenfekte ürünleri, arılaştırıcı, arındırıcı 
ürünler) annenin saflığı, temizliği ve dolayısıyla doğalığını çağrıştıracak şekilde kadın bedenin imgesi üzerine yerleştirilmiş ve birbirlerine bağlanmışlardır. Kadının en saf,

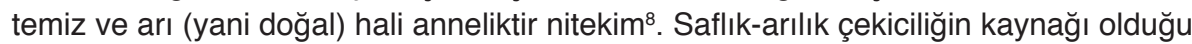
kadar kadının çağışstırdığı politik yüklere de (yukarıda tartıştığımız gibi) işaret eder. Sonuçta reklamlarda kadın bedeni, annelik imgelerinin üzerine nüfus ettiği ve ancak bu şekliyle doğallık mertebesine ulaşacağının ilan edildiği bir iğfale maruz kalmıştır. Bir imgeler havuzudur o artık. Kadına yönelik saflık ve temizlik ve olağanlığı temsil eden annelik ironik olarak tüm göndermeleri ile en toplumsal ve en sorumluluk gerektiren imgedir aynı zamanda. Üstelik bu temsil topluluğun da şerefinin türetildiği içerikleri oluşturmaktadır. Nitekim "kadınlar, topluluğun kimlik ve şerefinin, hem bireysel hem de kolektif olarak sembolik taşıyıcıları şeklinde kuruldukları için, çoğunlukla bu 'temsil yükü'nü taşımaları özellikle onlardan beklenmektedir" (Yuval-Davis, 2003, s. 93-94). Reklamların da kadına yönelik annelik beklentisinin şerefli yönlerde vurgulandığı popüler mecraları temsil etmeleri beklenebilir.

\section{Yöntem}

Annelik imgelerine ilişkin reklamları incelerken eleştirel bir ideoloji analizi gerçekleştirilecektir. Reklam analizlerinde sıklıkla kullanılan ve metinlerin ideolojik yapılarla ilişkisini tahlil etmeye çalışan yaklaşımların başında göstergebilim gelmektedir. Bu savın temel mantığı, reklamların anlam sistemleri arasındaki sürekli tercüme yaparak yaşamımızın farklı alanlarına ait değerlerin birbirinin yerine geçebilir hale getirildiği geniş bir meta-sistemi meydana getirmiş olmalarıdır. (Williamson, 2000, s. 25). Bir tür anlam oluşturma ve yapıştırma işlevi gören reklam metinlerinde söz konusu anlam kaynağını toplumsal süreçlerden devralır. Göstergebilimin en azından bazı içeriklerinde, söz konusu bu anlamın oluşum dinamiklerine yoğunlaşmaktadır. Bir gösterge başka bir şeyin yerine geçebilen herhangi bir şey olarak tanımlanabilir (Berger, 2014, s. 83). Yapısalcı göstergebilimin kurucusu olan Saussure'e (1998, s. 109) göre gösterge sistemlerinde bir nesneyle bir ad değil bir kavramla bir işitme imgesi birleşmektedir. Bunlar nedensiz ve çizgisel bağlantılardır. Göstergebilimin bir diğer öncü ismi Peirce'e göre (1931 aktaran Fiske, 1996, s. 125) de bir gösterge kendinden başka bir şeye göndermede bulunmakta ve biri tarafından anlaşılmaktadır. Göstergebilimde gösteren ve gösterilen üzerinde kurulmuş bir tür metinsel anlam kurulumundan söz edilir. Buna göre "gösteren, göstergenin algıladığımız imgesidir kağıt üzerindeki işaretlerdir, havadaki seslerdir. Gösterilen, gösterenin göndermede bulunduğu zihinsel kavramdır. Bu zihinsel kavram, aynı dili paylaşan aynı kültürün üyelerinin tümü için ortaktır” (Fiske, 1996, s. 67). Reklamların göstergebilimsel incelemesine göre insanların aldığı ürünlerin belli bir toplumsal sınıfı, statüyü, yaşam biçimini ya da ne isterseniz onu göstereceği varsayılır (Berger, 1993, s. 17). Dolayısıyla

8 Burada şunu açıkığa kavuşturmamız gerekiyor: "Doğal doğadan çıkarılıp alınan anlamdır ve ikisinin arasında görünmez, fakat anlaşılmaz olmayan bir engel vardır. 'Doğal', kültürün doğaya verdiği anlamdır; onun toplumsal olarak belirlendiği, sabit bir nitelik olmadığı 'doğal'ı oluşturan şeylerin çağdan çağa bütün tarih boyunca değişmesiyle gösterilir” (Williamson, 2000, s. 127). Bu nedenle anneliğin kadına ilişkin bir doğallıkla tanımlanması da toplumsal bir takım öndeyiler içerecektir. Bu biyolojik bir halin kültürlenmesi anlamında bir doğallaştırmadır. Bu, anneliğe ilişkin tarih-üstü veya tarih-dışı bir anlam yüklemenin imkânsızlığına işaret etmektedir. 
reklamda gördüğümüz ürün hem bir gösteren, hem de gösterilen olabilir. Bazen belirli ve bizim toplumsallık bağlamında ürettiğimiz değerlere işaret ederken kimi zaman da tam olarak onun kendisi olabilmektedir. Bu şekilde işaret edilmiş olmakla başka gösterge sistemlerinin de göstereni olabilir kuşkusuz (reklamlar ve diğer popüler kültür ürünleri arasındaki ilişkiyi düşünmemiz yeterli). Reklam süreci bu nedenle anlamlar arasında gezinen devingen bir mübadele sistemine karşılık gelmektedir.

Göstergebiliminde simgesel düzen belli gösterenlerin (dilsel öğeler) belli gösterilenlere (mitlerin anlamı) bağlı olarak anlamı sabitlediği; yapısal olarak sabitlenmiş anlamların özneleri, onların farkında bile olmadıkları bir tarzda belirlediği iddiası bulunmaktadır (Üşür, 1997, s. 79-80). Göstergebilimini ideolojik analizlere elverişli olarak evriltecek olan Barthes da ise bu işlemler doğrudan kurulmuş bağlantılar yerine yan anlamların esnekliği içerisinde gerçekleşir. Bir gösterenin (işaretin) tek ve dolaysız bir anlamı değil, başka anlamları (yan anlamları) da işaret etmesi mümkündür (Barthes, 1998, s. 42). Burada yan anlamsal bağlantıları tarihsel varlıklar olarak kuranlar bizlerizdir. Dolayısıyla anlamın takip edilmesinde bir zorunluluk ya da tamamen özgür bir birey düzeyinin arasında bir yere konumlanmış oluruz.

$\mathrm{Bu}$ yaklaşımda "bir reklam bildirisi, belli bir düzanlam şifresi taşır: Resimlerdeki görüntülerin tanınması, kullanılan konuşma dilinin anlaşılması gibi. Yananlam şifreleri ise, toplumda yaygın olan saygınlık, beğenilen kişilik, seçkin sayılma gibi bilinen toplumsal değer ölçülerine dayanır. Reklamın yananlamının şifresini toplumsal değer ölçülerinde aramak gerekir" (Yengin, 1993, s. 111-112). Bizim çalışmamız açısından da yukarıda tartışmaya çalıştığımız anneliğe ilişkin toplumsal kabuller, reklam görüntü ve metinlerinde aradığımız yan anlamsal içerikleri oluşturacaktır. Ancak burada özellikle reklam metninin özgül durumuna ilişkin Barthes'in bir uyarısına da kulak asmamız gerekiyor. Barthes'a göre asıl yan anlam yani ikinci bildiri metnin reklamsal niteliğidir, ikinci bildiri burada gizlice sunulmamaktadır (reklamlar hep bir uyarı ile sunulur); birinci bildiri ise ikinci bildiriyi (reklamı) daha ustaca ve daha ince bir biçimde doğal kılmaya yarar (1993, s. 164-165). Illk kabullerimiz bir bildiride toplumsal olarak bildiğimiz, tanıdığımız değerlerdir. Örneğin kadınsılığın güzellikle ilintili olduğunu düşünürüz toplumsal olarak; bir şampuan reklamı ise salt bir temizlik maddesinin tanıtımını yapmaktadır. Ama bu süreç içerisinde bir kayma yaşanarak, bizim toplumsal olarak bildiğimiz kadınsılık ve güzellik değeri, şampuanın kendisine aktarılmış olur. O, salt temizlik faaliyetinin değil, güzelliğin doğal unsurudur artık. Yani diğer tüm doğallıklar gibi toplumsallaşarak doğallaşmıştır. Aslında olan ise bir temizlik maddesinin satışa çıkarılmasıdır. Dolayısıyla tüm birincil bildirinin altında yatan ikincil nitelik çok da gizil olmayan metalaşma olgusunun kendisidir; yani maddi üretim süreçleri ve kapitalist ticaret ilişkileridir. Reklamın metayı toplumsal alana bağlayarak doğallaştırması da tam olarak budur. Bunu gerçekleştirirken de toplumun tarihsel kabullerini tarih üstü doğallıklar olarak kurgular. Biz de incelememizde bu birincil bildiriler (kapitalist üretim sürecini doğallaştırma işlevi yüklenen toplumsal değerler alanının) içersindeki yan anlamları çözümlemeye çalışacağız. Bu düzeyde anlamın nasıl yapılaştırıldığını ve izleyici açısından kesinlik taşımasa da kurulması muhtemel anlamsal dizgelerin neler olduğunu; bunların ne tür yan anlamlara ve doğallıklara tekabül ettiğini tahlil edeceğiz. 
Göstergebilimde kullanılan mit kavramı metinlerin toplumsal anlamları doğallaştırma işlevini açıklamak üzere kullanılır. "Mit bir kültürün, gerçekliğin ya da doğanın bazı görünümlerini açıklamasını ya da anlamasını sağlayan bir öyküdür. İlkel mitler yaşam ve ölüm, insan ve tanrılar, iyi ve kötü hakkındadır. Bizim sofistike mitlerimiz ise erillik ve dişillik, aile, başarı, bilim hakkındadırlar" (Fiske, 1996, s. 118). Kadının doğal hali olarak annelik kurgusunu da bu tür mitler arasına yerleştirmemiz mümkündür. Mitler kendi kökenleri ve dolayısıyla siyasal ve toplumsal boyutlarını gizemleştirirler ya da gizlerler" (Fiske, 1996, s. 119). Dolayısıyla anneliğin (kadın için kurgulanmış) doğallığına işaret eden reklam gösterileri bunun ardındaki toplumsal ilişkileri gizleme işlevi yüklenmektedir. Nitekim,

"Olağan dünyadan belli öğeleri, şeyleri ya da insanları seçme ve sonra yeni bir dünya, reklamın dünyasını yaratmak için bunları bir ürün miti gereğince yeniden düzenleme ve değiştirme. Bütün reklamcıı̆ğı özü budur: 'Gerçek' yaşamın, bizim yaşamamızın bileşenleri yeni bir dili reklamın dilini konuşmak için kullanılır” (Williamson, 2000, s. 23).

Öte yandan göstergebilimin temel kabullerinden biri olan şu olgunun altını çizmemiz gerekir: Göstergelerde dizgeler izleyici veya takipçilerinden bağımsız olarak oluşturulur. Kullanıcı gösterge aracılığıyla oluşturulan bu dilleri izler, onlardan bildiriler (sözler) alır, ama oluşturulmalarına katkıda bulunamaz (Barthes, 1993, s. 36). Ancak bizim perspektifimiz açısından reklamlarda anlamın kurulumu büyük ölçüde izleyicinin de ortaklaşa ürettiği bir faaliyet olarak görülmektedir. Bu nedenle analizimizde izleyiciler tarafından göstergenin işaret ettiği sınırların dışına çıkarak, metine ilişkin kurulması muhtemel bağlantıların ve kaçış imgelerinin de serimlemesi yapılmaya çalışılacaktır. Öte yandan izleyicilerin metinleri nasıl alımladıkları çalışmanın sınırları dışında kalmaktadır. Ancak bu alımlama düzeyinin de sınırsız olanaklara işaret etmediğine dikkat çekmek gerekir. "Metin hiçbir zaman 'tam' ideolojik kapanmaya ulaşmayan, ama bazı anlamları kapatırken ötekileri açabilen bir yapılandırılmış çokanlamlılık olarak işler" (Stevenson, 2015, s. 135). Dolayısıyla izleyicide etkili olan simgesel sistemleri de göz önünde bulundurmamız gerekir. Öte yandan alımlayıcıların sosyolojik arka planı da bu ortak simgesel alanın çözümlemesinde işlevsel olabilmektedir. İnceleme konumuz açısından bakıldığında da reklamların bu tür bir ortaklık ekseninde üretilmiş olduğunu görebilmemiz mümkündür. Söz konusu bu anlatılar orta sınıf Türk ailesine seslenen içeriklere sahiptir çoğunlukla. Bu nedenle çalışmanın reklamlara yönelik analizi, bu ortak kodların tespit edilmesine yöneliktir. Kısacası buradaki incelemenin kendisini metnin anlam üretme kapasitesi ve bu faaliyetin ortak toplumsal değerleri nasıl yeniden ürettiği ile sınırlandırdığını belirtmemiz gerekir. Nitekim elimizdeki reklam metinleri herhangi bir farklılık talebine karşılık gelmeye çabalasalar da toplumsal ilişkilerin belirli bir tarihsel dönemde somutlaşmış ve nesneleşmiş çıktısından başka bir şey değildir.

Değerlendirilmek üzere seçilen reklamlar 2015 yılı ile 2017 yılı arasında youtube'a yüklenen popüler reklamlardan seçilmiştir. Reklamların siteye yüklenme tarihleri kaynakçada belirtilmektedir. Arama motorunda "anne" kelimesine karşılık gelen reklamlar arasından bir tercihte bulunulmuştur. Reklamların seçilmesinde özellikle anneyi merkeze koyan, göndermelerini annelik üzerinde yoğunlaştıran reklamlar 
analize tabi tutulmuştur. Söz konusu tarihler arasında beş reklamın annelik imgesini özellikle ön plana çıkaran içeriklere sahip olduğu görüldüğünden örneklem beş reklam üzerinden sınırlandırılmıştır.

\section{Reklam analizleri}

\subsection{Eksiltilen kadın ve anne}

Gösterge Sistemi: Reklamda söz ve görsel öğelerin hepsi bankanın göstereni durumundadır. Öte yandan her gösteren kendi içinde de bir gösterge sistemi barındırır. Reklam bir yılbaşı partisinde erkeğin eşinin davranışlarını izlemesi üzerine kurulmuş bir dizgeye sahiptir. Erkek eşini izlerken bir dış ses onunla konuşur. "Biricik aşkın Aslı yeni yılda anne olmaya hazır" göstereni ile kadının partideki diğer hamile, çocuklu kadın ve çocuklarla yakınlaşması gösterilir. "Samimiyetle hazır. Gayretiyle hazır. Israrla hazır" ifadeleri eşliğinde görsel olarak kadının çocuklarla ilgilenirken yaşadığı sakarlıklar aktarılır. Komiklik yaptığı çocuk ona gülmemesine rağmen "Emre bak sevdi beni" der örneğin ya da oynamaya çalıştığı bir başka çocuk ona yüz vermez, yemek yedirmek istediği çocuk ağlar. Hatta bir çocukla oyun oynamaya çalışırken yılbaşı ağacını devirir. Dış ses "hem de çok hazır" diyerek araya girdikten sonra kadraja giren erkeğe "Peki sen baba olmaya hazır mısın? Emre. Oturma odası, bezi, okulu hı? Hazırsın hazır. Çünkü X bankta nakit hazır" şeklinde seslenir. Erkek önce şaşırmış görünür ama her haliyle hazırlıklı olduğunu ifade eden bir mimikle dinlemektedir bu sözleri.

Düz anlam: Kadının çocuk istemesi artık belirli bir dönemden sonra doğaldır. Çocuk yetiştirmek, onlarla ilgilenmek zordur. Bunları aşmak ise göründüğü kadar zor değildir. Erkek ve banka bu gibi sorunları çözecektir.

Yan anlam: Erkek sorunu çözen rasyoneliteyi temsil eder. Bankanın da bu rasyoneliteye eklemlendiği görülmektedir. Kadın ise arzunun peşinden (burada çocuk) tutku ile koşmasıyla duygusallığı ve akıl dışı davranışları ile yeniden üretilmektedir. Sürekli sakarlıkları bu tür akıl dışılığa taşan davranışlarının işaretidir.

Mit: Her kadın anne olmak ister. Annelik doğal bir kadınlık talebidir. Hatta bu uğurda yani bir arzusunu yerine getirmek için kadın akli melekelerini ve kontrolünü de kaybeder. Kadın duygusal bir varlıktır. Annelik de bunun bir uzantısıdır. Metnin bir de erkeklik üzerine ürettiği bir miti bulunmaktadır. Erkek baba olmak ister ama bunu rasyonel bir şekilde talep eder. Yeri ve zamanı önemlidir. Erkek rasyoneldir.

Değerlendirme: Kadınlık burada, eksiklikle tanımlanmıştır. Kadın eksikli varlığını duygusallığa işaret eden bir pasiflikten tesis etmektedir. Akıl ve düzenli davranışlar kadında bulunmaz; o duygularının peşinde koşmakla komik duruma düşmüştür. Nitekim "Beyin erkeği, aklı, toplumsalı, yazarlığı; beden ise kadını, duygusallığı, irrasyonaliteyi, dışlanmış olanı temsil eder" (Satar, 2015, s. 71). Metindeki kadın da eksikliğini bu irrasyonellikten kazanmaktadır. Bu eksikliği giderecek çözüm önerisi ise reklamın sonunda erkeğe dönen kamera tarafından gösterilir. Onun kaygıları ve öngörüleri 
kadına ilişkin eksikli durumu telafi edecektir. Bankanın (meta) üzerine devraldığı değer de büyük ölçüde bu erkeksi akıl, hazırılık ve öngörüdür. Böylece tanıtımı yapılan meta, toplumsal alanda üretilmiş cinsiyet 'doğallıklarının' arasına kendini yerleştirmiş olur. Banka erkektir, kadın ise pasiflik ve duygusallıkla konumlanmış izleyicinin kendisidir.

\subsection{Her ișin arkasındaki gizemli/görünmeyen anne}

Gösterge sistemi: Reklam bir elektrik süpürgesine ait gösterenlerle şekillenmektedir. İlk olarak evde maç seyreden baba, maçın heyecanlı bir yerinde kuruyemiş tabağını düşürür. Ancak göz açıp kapayıncaya kadar yerdeki kuruyemişler elektrik süpürgesi ile temizlenir. İkinci olarak kız çocuğu evin içinde bir bibloyu kırar aynı hızda bu da temizlenmiştir. Çocuk etrafına şaşırarak bakar, az önce kırılan ve yere saçılan biblo yok olmuştur. Fazla üzerinde durmadan oyununa devam eder. Benzer bir şeyi evin kedisi de yapar ve aynı hızla neden olduğu zarar ortadan kaldırılır. Dış ses "eyvah desen de kırılır aman desen de dökülür" dedikten sonra elektrik süpürgesinin tanıtımına geçer. En sonunda "evdeki yaramazlar harekete geçtiğinde yanındayız" denilerek elektrik süpürgesi ile poz veren bir kadının görüntüsüne yer verilir. Gösterge sistemin diğer alt gösterge denklikleri şu şekilde tarif edilebilir: Elektrik süpürgesi (gösteren) görünmeyen kadın (gösterilen), maç (gösteren) erkek (gösterilen), baba, çocuk ve kedi (gösteren) yaramazlık (gösterilen), temizlik etkinliği (gösteren) anne (gösterilen).

Düz anlam: Evin içinde doğal olarak istenmeyen durumlarla karşılaşabiliriz. Çocuk ve kedi yaramazlıklarından ötürü eve zarar verebilir düzeni bozabilirler, erkek de bu doğallığa sahiptir. Anne, sessiz çalışan bir elektrik süpürgesi ile bu düzensizliği ortadan kaldırır, evin sorumluluğu ve düzenin tesisi anne tarafından gerçekleştirilecektir. Araç bu işe yardımcı olur.

Yan anlam: Anne düzenleyici, toparlayıcı varlıktır, evin içindeki statüsü ikincildir. Evin konforundan yararlananların çıkardığı sorunları ortadan kaldıran bir hizmetlidir o. Evin doğal halinin koruyucu kadın/annedir.

Mit: Anne doğal olarak evin düzeninin sorumlusudur. Anne bakıcıdır, toparlayıcıdır ve üstelik bunu öyle bir doğallıkla gerçekleştirir ki görünmesine bile gerek yoktur.

Değerlendirme: Gösterge sistemi içerisinde en büyük gösterilen elektrik süpürgesi ile ayırt edilemez bir dolayıma girmiş annedir. Elektrik süpürgesinin sessizliğine gönderme yapacak şekilde anne reklamın sonuna kadar orada değil gibidir. Diğer bir ifade ile tekrar eksiltilmiş bir anne ile karşılaşmaktayız. Orada bulunmayış, anlamlandırma pratiklerinde anlamın yerleştirilmesini izleyicinin üretimine bırakan bir yönelime sahiptir. Bu metinde de anne orada bulunmaz ama sessiz elektrik süpürgesinin gösterdiği olarak hep yanı başımızdadır. Orada bulunmayan anne, tüm yoksunluğu ile gösterilmiştir. Efendi-köle ilişkisinin ikinci kanadındaki odur. Hep her yerdedir, her şeydedir, hep göz önündedir ama görülmeye değer değildir. Kendisini boş ve ilişkisiz kıldığında kadın asıında başkayı da serbest bırakmış olmaktadır. (Direk, 2018, s. 144) 
Bu bir tanınma talebine de işaret eder gibidir. Çünkü erkeği tanımlayan kadındır. Ama tanınma olayının kendisi ortada yoktur. Bu saf tanıma olayının gerçekleşebileceğini ima eder, tanıma olayı ise henüz ortada yoktur (Direk, 2018, s. 144). Ama reklam metni bu boşluğu doldurur. Nitekim reklamda her işin arkasında görünmeyen kadın vardır. Elektrik süpürgesinin ardındaki de odur. Reklam metninin metaya yüklediği değer de buradan devşirilmiş görünmektedir.

\subsection{Milli annelik}

Gösterge Sistemi: Uçan bir uçağın görüntüsü ile başlayan reklamda pilotun anonsunu duyuyoruz ilk olarak. Anonsta birazdan ikram servisinin başlayacağı ancak bugün yemekleri kendilerinin hazırlamadığı belirtilmektedir. Görüntülerden bunun Türk Milli takımını taşıyan uçak olduğu anlaşılmaktadır. Ardından futbolcuların şaşkınlıkla dinlediği şu duyuru yapılmaktadır: "bu yolculuk öncesi çok değerli annelerinizin mutfağına misafir olduk ve sizlere onlardan mesajlar getirdik. Hepinize şimdiden afiyet olsun". Anonsun ardından uçakta paylaşılan görüntülerde milli futbolcuların anneleri mutfakta yemek hazırlarken görülmekte, futbolcular da eğlenerek ve ardından duygulanarak annelerinin mesajlarını ve görüntülerini izlemektedirler. Anneler bu görüntülerde mutfakta ne yemek yaptıklarını aktararak tüm futbolculara iyi dilek ve başarı temennilerini sunarlar. Anneler temennilerini şu şekilde aktarırlar: "Yemeklerimizi biz ellerimizle yaptık siz yüreklerinizle oynayın", "Başaracağınıza yürekten inanıyorum dualarımız sizinle", "Hepinize şifa olsun, enerji olsun", "Afiyet bal şeker olsun, kuvvet olsun inşallah". Futbolcular son temenniden sonra hep birlikte "âmin" derler. Bir annenin "Hadi göreyim sizi evlatlarım" şeklindeki açıklamasından sonra da uçaktaki futbolcular hep birlikte alkışlar. Bu sırada kimi futbolcuların duygulandığı da görülür. Reklamın sonunda futbolcuların annelerin hazırladığı menüden oluşan yemekleri mutlu bir şekilde yedikleri görünür. Reklam bir annenin "yolunuz açık olsun çocuklarım" çağrısıyla sonlanır. Reklamın anne ve erkek çocukları arasında kurulan bağı hava yolları şirketinin kendisine aktaran büyük bir gösterge sisteminden oluştuğunu görmemiz mümkün. Daha alt kategorilerde ise futbolcuların Türk toplumunu ve uçağın da Türkiye'yi gösterdiğine işaret edebiliriz.

Düz anlam: Türk milli takımının futbolcuları tüm Türkiye'yi temsil eder. Annelerin mutfaklarında yaptıkları yemekler çocukların başarılı olmasını sağlayacaktır. Anneler iyi, lezzetli yemek yapar. Uzakta iken annelere özlem duyulur.

Yan anlam: Başarılı erkek çocukların arkasındaki gizli kahraman anneleridir. Onların duaları ve yemekleri başarının önemli bir vesilesi olarak sunulur. Annenin belirgin sunumu onları mutfakta göstermektedir. Reklamın ana teması da anneler tarafından hazırlanmış menüler olması nedeniyle bu toplumsal ve tarihsel durumu doğallaştırır. Annelik yemek yapmakla özdeşleşmiştir. Dolayısıyla annelik, bakım, itina ve kollama (dualar da buna işaret eder) görevleri ile donatılmıştır. Öte yandan bu vasıflar milli futbol takımının tüm ulusu işaret etmesi sebebiyle Türk annesinin de nitelikleridir. Türk annesi duası, yemeği, özeni ve sıcaklığı ile oğulların arkasındaki manevi kuvvettir. 
Mit: Türk annesi doğal olarak erkek çocukların başarısının arkasındaki kuvvettir. Anne, milli içeriklere sahiptir. Onun doğası dayanışmayı tesis etmekle ve yeniden üretmekle çizilmektedir.

Değerlendirme: Reklamın anneliğe yüklenen politik bir içerikle şekillendiğini ifade edebiliriz. Bu politik ifade büyük ölçüde anneliğin belirli türde tanımlanmış toplumsal pratiklerini milli bir kimlik etrafında toparlamaktadır. Kuramsal boyutta ele alınan annelik ile politik değerler arasında bir bağ bulunduğu savı burada görünür olmaktadır. Bu bağa göre kadınlar, vatandaşlık görevi ve kültürel bir belirleyen olarak sunulan askerlik görevi yerine başka bir temel görevle donatılırlar o da anneliktir (Kancı, 2015, s. 89). Koruyucu, mutfakta çocukları için yemek pişiren ve sürekli onların başarısı ve sağlığı için dua eden anne, aynı zamanda Türk annesinin temel niteliği olarak da görülebilir. Zaten reklamdaki annelerin hazırladıkları yemekler futbolcuların hepsi için hazırlanmıştır. Anne dolayısıyla yemeği ile toparlayıcı, birleştirici ve dayanışma ruhunu yeniden üreten bir niteliğe sahiptir. Bu bakıcı anne hepimizin annesidir. Ulusun ortak annesi, Anadolu'nun sıradan kadınıdır.

\subsection{Anneler sevgi, para, anı her șeyi biriktirir}

Gösterge Sistemi: Reklam bir annenin yanında çocuğu ile birlikte elleri alışveriş torbaları ile dolu iken eve gelişini göstererek başlar. Anneyi evin kızı karşılar. Eşyaları kızına veren anne cebindeki bozuk paraları hemen holdeki bir kavanoza koyar. Bu sırada görüntülerle birlikte müziğin sözleri de devreye girer. Şarkıda "biriktirir, biriktirir anneler biriktirir. Köfte yapar lezzet katar" sözleri duyulur. Bu sırada kadının mutfakta çalışması ve akşam sofrada ailenin diğer üyeleri yemeklerini yerken yüzündeki mutluluğu ile gösterilir. Şarkının nakaratı devreye girdiğinde annenin başka türlü biriktirme etkinlikleri de sergilenir. Duvara fotoğraf asar, çocuklarının eski eşyalarını saklar. Bu arada şarkıda "her bişeyi saklamalı kapları biriktirir" denilirken annenin çocukları için dondurma kabında yemek sakladığı da gösterilir. "Hijyen için çantasında mendiller biriktirir" denilirken de annenin çocuğun yüzündeki kirleri temizlediği görünür. Annenin eşofmanla mutfakta aerobik yaparken gösterildiği sahneden hemen sonra da annenin bizim için sağlık için haberler biriktirdiği ifade edilir. Anne sağlıkla ilgili gazete kupürlerini kesmekte ve çocuklarına buradan öğrendiği yiyecekleri sunmaktadır (çocuklar gönülsüz olsa da). Reklamda annenin sürekli olarak kavanozlarda reçel, turşu, konserve gibi şeyler biriktirdiği daha sonra da fotoğraflar ve anılar biriktirdiği de gösterilir. Reklamın sonunda da şarkının temposu azalırken şunlar söylenir: "Hayal kurar nakış yapar, çeyizlik biriktirir, öper koklar, sever, sarar, sevgiyle biriktirir”. Çeyizlik biriktirirken anne duygu yüklü bir şekilde kızına bakar. Daha sonra iki çocuğunu öper ve kucaklar. Bu sırada reklamın gösterileni olarak bankanın amblemi devreye girer ve reklam sonlanır. Reklamın merkezindeki anne temel gösterendir. İyi yemek yapmayı, bakımı, biriktirmeyi, evin ekonomisini düzenlemeyi, sevgiyi düzenlemeyi, anıları üst üste koymayı (tarihi yeniden oluşturmayı), geleceği şekillendirmeyi gerçekleştiren o’dur. Bankanın anneden üzerine devşirdiği değer ve anlamlardır bunlar.

Düz anlam: Anne; tutumlu, tertipli, yoktan var eden ve ev ekonomisine katkı sağlayan 
kişidir. Ayrıca anne, evi sıcak bir yuvaya, yaptığı yemekler ve çocuk sevgisiyle dönüştüren kişidir.

Yan Anlam: Anneye ilişkin alışveriş, para biriktirme, konserve ve reçel yapma, yemek yapma gibi toplumsal cinsiyet rollerinin vurgulanması evi yuvaya dönüştürmektedir. Biriktirmek ile yuva arasında kurulan bir bağlantıdan söz etmek mümkündür. Foucault'nun teşhisinde bu yuvanın ilk hali barınaktır. Barınak biri erkeğe bağlı olan, diğeri ise kadının ayrıcalıklı yerini oluşturan bir dış ve iç bölgeyi belirtir; ama barınak aynı zamanda da kazanılanın toplandığı biriktirildiği ve saklandığı yerdir... Sonuç olarak dışarıda eken, yetiştiren, biçen, sürüleri besleyen erkek olacaktır; ürettiği, kazandığı ya da takas ettiğini eve getirir; içeride kadın bunu alır, saklar ve gereksinimlerine göre verir (Foucault, 2013, s. 227). Kadın barınak ya da yuvaya giren malları düzene sokan bir sorumluluğu sahiptir. Barınağın içi kadına aittir. Dolayısıyla ait olduğu yer de oradan tanımlanır. Reklamda da annenin ev ve evde yaşayan bireyler için varlığının önemine değinilmektedir. Yapılan sağlıklı yiyeceklerle yeni nesiller, anne tarafından yetiştirilmektedir. Kutsal annelik ile kadın özdeşleştirilmiş ve kadın çalışmasa bile kavanoza para üstlerini koyarak, evde konserve/reçel yaparak ev ekonomisine fazlasıyla katkı sağlayan bir figür olarak çizilmiştir. Ayrıca annenin (kadının) kendi üzerine hayallerinden ziyade çocukları -ki burada kız çocuğuna işaret edilir- üzerine kurduğu hayaller gösterilerek anne kendinden vazgeçen, çocukları ve ailesi için yaşayan bir unsura dönüştürülmüştür. Bu dönüşümün taşıyıcısı olarak da reklamda kız çocuğuna dikkat çekilir. Kız çocuğu için kurulan hayaller arasında çeyiz imgesinin girmesi ile kızın geleceğin annesi olduğunun altı çizilmektedir.

Mit: Anne yaşam alanı olan evi çekip çeviren, düzenleyen kişidir. Anne evi ve çocukları için yaşayan ve topluma sağlıklı nesiller yetiştiren biridir.

Değerlendirme: Anne reklamda genel anlamıyla toplumsal cinsiyet rolleri dahilinde çizilmiştir. Yuvası ve çocukları için yaşayan, evi düzenleyen, ev dışında bir dünyası olmayan biridir anne. Burada iş, salt bir ev işi sürecini gerçekleştirmek değildir. İşle tanımlanan şey aynı zamanda yuvanın zihinsel olarak kurgulanışıdır. Kadınların yaptığı yuva işi olarak zihinsel bir iştir (Bora, 2012, s. 125) İş, yuvayı mümkün kılar. Bu bağlamıyla ev işi simgesel bir üretime de karşılık gelmektedir. Kadının yaşam alanını da ev olarak çizen reklam, kadının konumunu annelikle sabitleyerek bu yuva işine işaret etmektedir. Ayrıca reklamda annelerin biriktirmesine vurgu yapılarak bankanın anne gibi biriktiren kucaklayıcı yapısına dikkat çekilmektedir. Anne bankanın gösterenidir. Diğer bir ifade ile anne ve banka arasında kurulan ilişkinin mahiyeti annelik kodlarının bankayı çağrıştıracak şekilde dizayn edilmesiyle gerçekleştirilmektedir. Annelik kodları ile tanımlanmış banka evimiz gibi sıcaktır artık.

\subsection{Anne olmak}

Gösterge Sistemi: Reklam bir göze odaklanan görüntüyle başlıyor. Gözden yansıyan hatıralar devreye girerken dış ses anne olmayı tasvir etmeye başlıyor. Anne ile çocuğu 
arasındaki ilişkiyi görsel olarak bir anne ve çocuk imgeleri ile sunarken dış ses şunları söylemektedir: "Anne olmak o ilk bakışında, başını ilk yaslayışında, ayağa ilk kalkışında, ilk düşüşünde ve ilk vazgeçmeyişinde, ilk adımında, kendini ilk ifade edişinde (anne der bebek)”. Görüntüde çocuk büyüdükçe dış sesin anlatımı devam eder. Bir annenin çocuğunun ödeviyle ilgilendiğini gösteren görüntüde (bir yandan çocuğun başını öpmektedir) dış ses, "ilk probleminde yanında olmaktı" demektedir. Daha sonra çocuğun evden ayrılışı üniversiteye gidişi ve evlendiğine ilişkin görüntüler sunulurken arka fonda şunlar söylenmektedir: "Anne olmak ilk gidişinde ve ilk dönüşünde, hayata ilk atılışında (mezuniyet töreni görüntüsü eşliğinde), tüm kalbiyle ilk 'evet' dediğinde (kızın gelinlikle annesine sarıldığı görülür) orada olmaktır". Anne evdeki fotoğraf albümlerine bakarken dış ses, "Anne olmak onun için hep iyisini istemektir. Çünkü o, annesinin gözbebeğidir. Teşekkürler annesi” derken reklamda sona erer.

Düz anlam: Anne olmak çocuğun büyüme sürecinde her an yanında olmayı gerektirir. Çocuğun yetişkin bir birey olması annesiyle kurduğu ilişkinin yakınlığına bağlıdır. $\mathrm{Bu}$ ilişki gösterge sistemindeki kimi öğelerde işaret edildiği gibi duygusal bir bağdır. Evlenirken annenin gözlerinin dolması, annenin şefkatli bakış ve duruşları bunu yansıtmaktadır.

Yan anlam: Göstergenin dışta bıraktığı içerikler yan anlamın oluşmasında etkilidir. Reklamda çocuk ile kurulan ilişkide baba figürü yoktur. Bu bir yanıyla erkeksiz bir çocuk yetiştirmeye yönelik olumlu bir alımlayıcı kategorisi oluşturabilir. Öte yandan çocuk yetiştirmekle ilgili sorumluluğu doğrudan kadının kendisine yükleyen bir okumaya da açıktır. Zira her ilkte anne çocuğun yanındadır. Annelik duygusal bir bağlanmayı ifade eder. Reklamın bu bağlamda görünmeyen erkekle bir tür ikiliği ürettiğini söylememiz mümkün görünüyor. Annelik duygudaşlığı, şefkati, bağlıı̆̆ı ve sakınımlığı ifade ederken, bunu boş gösteren olarak bir erkek kurgusunun karşıtı olarak inşa eder.

Mit: Kadın doğal olarak annedir. Anne olmak da doğal olarak bir duygusallığa işaret eder. Şefkat ve bağlılık anneliğin doğal görünümleridir. Hayatı kuran annedir, çünkü çocuğun her aşamasında yanında olan o'dur. Dolayısıyla anne doğa gibidir; sunandır o.

Değerlendirme: Reklamın başlangıcında kameranın göze odaklanması ve oradan hatıralara geçiş sağlanması, bakma ve sorumluluk görevlerini çağrıştırmaktadır. Zaten reklamın sonunda bu açıkça belirtilmiştir: "Çünkü o, annesinin gözbebeğidir." Anne, bakan, sorumluluk duyan, çocuğunun her zaman yanında olması gereken tek varlık olarak sunulur reklam boyunca. Nitekim okul eğitimine destek vermek, hijyen, ruhsal sağlık gibi argümanlar ekseninde annelik son derece güçlü bir pozisyon olarak yapılandırılmıştır (Aytaç, 2007, s. 103). Bu güç annenin çocuğu izleyen gözünden kaynaklanır. Görünen, annenin gözünün gördüğüdür yalnızca. Bu görünen evrende ise çocuk merkezde yer almaktadır. Kadının bütünlüğü bu gösterge sisteminde olduğu gibi çocuğu ile kurduğu iliş̧ide gizlidir. Anne ve çocuk bir bütünlük oluşturmuştur . Böylece

9 Nitekim, Badinter'e göre de (2015, s. 125) "hiç doğurmamış kadın olmak" ifadesi, kadını anne ile özdeşleştirmektedir; eksiklik ve bitmemişliğe gönderme yapar... Hiç doğurmamış kadın, özünden ve dünyadaki yerinden yoksun kalmıştır. 
kadının eksikliği kapatılmış olur. Reklam metninin genellikle toplumsal açıklıklara işaret ederek bu mesafeleri ürünle doldurduğu düşünüldüğünde reklam metninin önerdiği şey ürün ile birlikte anneliğin kendisi haline gelmektedir. Annelik aynı zamanda çocuk içinde tamamlayıcı bir işlev yüklenmiştir reklamda. En önemli anlarda orada olmak çocuk için de tamamlayıcılık görevi gören bir anneliğe işaret eder. Annelik böylece kadın için (reklamda çocuk da kadındır) arzulanan bir orada bulunuştur. Orada bulunmanın vesilesidir anne olmak, önemliliği tesis eden şey annenin orada olmasıdır. Böylece kadın için doğal bir annelik arayışından farklı bir şey beklenemez hale gelmiştir çoktan.

\section{Sonuc}

Annelik kadına yönelik bir tamlayıcı imge olarak işlev görmekte ve kadınlığın en "doğal" hali olarak kabul görmektedir. Annelik bu doğallık mitini toplumsal alanda kazanmaktadır. Ancak doğallık şeklinde kurulduğu sürece sarsılmaz bir kutsaliyetle de donatılmış olur. Bu nedenle annelik, toplumsal alanın birçok imge ve değerle yüklediği merkezi bir kimliksel duraktır. Annelik özel alanın kamusal değerlerle şekillenmesini sağlayan bir aracıdır. Toplumsalın değerlerini eve taşıyan veya evde üretilmiş değerleri kamusallaştıran bir içeriğe sahiptir. $\mathrm{O}$, milli değer ve kimlikleri aktaran, bireysel başarıların ve yeterliklerin inşa edilmesine ön ayak olan, evin merkezinde yer alan, geleneği sürdüren, modern yaşama uyum gösteren, duyguların taşıyıcısı olmakla kadına yönelik eksikliklerin giderildiği bir mecra-bedendir. Ancak bu eksikliği gideriyor olmakla annelik, kadınlığın cinsiyetsizleştirildiği bir imgeleme de karşılık gelir. Annelik, kadının cinselliğinden duyulan kamusal endişenin de toparlandığı, düzlendiği bir kimlik olarak karşımıza çıkar.

Reklamların temas ettiği annelik kodları da benzer içeriklerle şekillenmiştir. Reklamlar toplumsal hayatta bizlere eksikli varlıklar olarak seslenir. Güzelliğimiz, çekiciliğimiz, saçımızın deforme olmasını giderme vaadi içeren metalardır reklamın merkezi imgesi. Annelik de kadının toplumsallaşma pratiğinin en makbul yolu olarak sunulur reklamlarda. Aslında annelik imgesi, kadının duyumsadığı eksikliğin toplumsal kabule ilişkin olduğunu çağrıştırır bize. Kadın anne olmakla, toplumsal alandaki meşruluğunu inşa etme yollarından yoksun bırakılmışığını telafi eder gibidir. Bu yol ancak anne olunca açılacaktır. Reklamlar bu yolun taşlarını dizer önümüze. Hangisine basarak ilerleyeceğimizi, eksikliğimizi nasıl telafi edeceğimizi ve anneliğin nasıl da olması gereken bir doğallık olduğunu imleyeceklerdir.

Öte yandan ele alınan reklamların izleyiciler tarafından olduğu gibi kabul edildiğini ve annelik kodlarının sırf bu yolla inşa edilmiş olduğunu söylemek de doğru olmayacaktır kuşkusuz. Ancak yine de anneliğe ilişkin toplumsal kabullere sızmamızı sağlayan bir özelliği var reklamların. Reklamlar her şeyden önce metaların «en fazla» satışını gerçekleştirmek için toplumsal değerlerin de çoğunlukla en fazlasına işaret etmek durumundadır. Bunu bir tür yansıma olarak da kabul edemeyiz. Reklamlar aynı zamanda kurucu bir işlev de yüklenir, tek başlarına olmasa da... Reklamlar toplumsal alanın zengin kaynaklarının ve oluşturucularının içinde onlarla birlikte üretilmiş anlam ve değerlerin billurlaşmış alanları olarak tahayyül edilebilirler. Reklamlardaki 
anne imgesi de toplumsalın kabullerine ilişkin bir takım kesişim noktalarına işaret eder. Burada toplumun inşa ettiği yaratıcı bir imge olarak anne, yine bize nasıl biz olacağımızı göstermektedir, tüm eksikliğiyle...

\section{Kaynakça}

Aytaç, A. M. (2007). Ailenin serencamı. Ankara: Dipnot Yayınevi.

Badinter, E. (2015). Kadınlık mı annelik mi (A. Ekmekçi, Çev.), İstanbul: İletişim.

Bal, S. (2014). Reklamların eskimeyen yüzü 'Muhteşem Annelik': Anneler günü reklamları örneği. ilef, 1(2), 59-87.

Barthes, R. (1993). Göstergebilimsel serüven (M. Rifat ve S. Rifat, Çev.). İstanbul: Yapı Kredi Yayınları.

Barthes, R. (1998). Çağdaş söylenler (T. Yücel, Çev.). İstanbul: Metis Yayınları.

Berger, A. A. (1993). Kitle iletişiminde çözümleme yöntemleri (M. Barkan ve N.Bayram, Çev.). Eskişehir: Bilimsel Araştırma Çalışmaları Vakfı Yayınları.

Berger, A. A. (2014). Kültür eleştirisi (Ö. Emir, Çev.). İstanbul: Pinhan Yayıncılık.

Binark, M. (2014). Kadınlar ve popüler roman okuma edimi: Erol Mutlu'nun düşündükleri ve düşündürdükleri. B. Kejanlıoğlu, E. Çaylı Rahte, v.d., (Der.), İletişim anlam arayış Erol Mutlu’ya armağan içinde (s.242-252). Ankara: Ütopya Yayınevi.

Bora, A. (2012). Kadınların sınıfı ücretli ev emeği ve kadın öznelliğinin inşası. İstanbul: İletişim Yayınları.

Bora, A. (2013). Rüyası ömrümüzün çünkü eşyaya siner. A. Alkan (Der.), Cins cins mekan içinde (s. 63-75). İstanbul: Varlık Yayınları.

Çaylı Rahte, E. (2014). Popüler kültürü eleştirmek üzerine: Oskay, Oktay ve Mutlu. B. Kejanlıŏlu, E. Çaylı Rahte, v.d. (Der.), İletişim anlam arayış Erol Mutlu'ya armağan içinde (s.252-276). Ankara: Ütopya Yayınevi.

Demirci Yılmaz, T. (2015). Osmanlı ve erken cumhuriyet dönemi Türkiye modernleşmesinde annelik kurgusu. Cogito, 81, 66-91.

Direk, Z. (2018). Cinsel farkın inşası. İstanbul: Metis Yayınları.

Fiske, J. (1996). İletişim çalışmalarına giriş (S. İrvan, Çev.). Ankara: Bilim Sanat Yayınları.

Foucault, M. (2013). Cinselliğin tarihi (H. U. Tanrı̈̈ver, Çev.). İstanbul: Ayrıntı Yayınları.

Funk, R. (2007). Ben ve biz postmodern insanın psikanalizi (Ç. Tanyeri, Çev.). İstanbul: Yapı Kredi Yayınları.

Freud, S. (2016). Cinsellik üzerine (S. Budak, Çev.). İstanbul: Öteki Yayınevi.

Gittins, D. (2011). Aile sorgulanıyor (T. Erdem, Çev.). İstanbul: Pencere Yayınları.

Hançer, A. (2018). Toplumsal cinsiyet öznesi olarak kadının 'Annelik' kimliğine eleştirel bir bakış. 
Akdeniz Kadın Çalışmaları ve Toplumsal Cinsiyet Dergisi, 2, 177-202.

Işık, S. Y. (2015). Küresel kültürel değişim ve 'yeni' annelik: Ankara Kamil Ocak Mahallesi örneği. Eğitim Bilim Toplum Dergisi, 13(50), 48-75.

Kancı, T. (2015). Türkiye'de eğitim, milliyetçilik ve toplumsal cinsiyetin kesişim noktaları. S. Çoşar ve A. Özman (Der.), Milliyetçilik ve toplumsal cinsiyet içinde (s.77-109). İstanbul: Illetişim Yayınları.

Korkmaz, N.ve Yaylagül, L. (2008). Kitle kültürü / Popüler kültür tartışmaları. L. Yaylagül ve N. Korkmaz (Der.), Medya, popüler kültür ve ideoloji içinde (s.105-124). Ankara: Dipnot Yayınevi.

Lull, J.(2001). Medya iletişim kültür (N. Güngör, Çev.). Ankara: Vadi Yayınları.

Mitchell, J. (2006). Kadınlar en uzun devrim (F. Tınç, G. Savran, G. İnal, v.d., Çev.). İstanbul: Agorakitaplığı.

Modleski, T. (1998). Eğlence incelemeleri (N. Gürbilek, Çev.). İstanbul: Metis Yayınları.

Öztan, E. (2015). Annelik, söylem ve siyaset. Cogito, 81, 91-108.

Poster, M.(1989). Eleştirel aile kuramı (H. Tapınç, Çev.). İstanbul: Ayrıntı Yayınları.

Rutherford, P. (2000). Yeni ikonalar (M. K. Gerçeker, Çev.). İstanbul: Yapı Kredi Yayınları.

Sancar, S. (2012). Türk modernleşmesinin cinsiyeti. İstanbul: Iletişim Yayınları.

Satar, N. A. (2015). Geleneksel kadın rollerinin yeniden üretimi: Elif Şafak'ın Siyah Süt romanında otoriteyle uzlaşmak. Monograf, 3, 46-77.

Saussure, F. De (1998). Genel dilbilim dersleri (B. Vardar, Çev.). İstanbul: Multilingual.

Sektanber, A. (2011). Türkiye'de medyada kadın: Serbest, müsait kadın veya iyi eş, fedakar anne. Ş. Tekeli (Der.), 1980’ler Türkiyesi'nde kadın bakış açısından kadınlar içinde (s.187-207). İstanbul: İletişim Yayınları.

Sever, M. (2015). Kadınıı, annelik, gönüllü çocuksuzluk: Elisabeth Badinter'den kadınlık mı annelik mi?, Tina Miller'dan Annelik duygusu: Mitler ve deneyimler ve Corinne Maier'den No Kid üzerinden bir karşılaştırmalı okuma çalışması. Fe Dergi, 7(2), 72-85.

Stevenson, N. (2015). Medya kültürleri - Sosyal teori ve kitle iletişimi (G. Orhon, ve B. E. Aksoy, Çev.). Ankara: Ütopya Yayınevi.

Türkdoğan, Ö. (2013). Ana akım medyada annelik miti. Kadın Araştırmaları Dergisi. 2(13), 35-59.

Uğurlu, E. G. (2013). Annelik rolünün öğrenilme sürecinde medyanın yeri. Erciyes Üniversitesi Sosyal Bilimler Enstitüsü Dergisi, 1-24.

Üşür, S. S.(1997). İdeolojinin serüveni, yanlış bilinç ve hegemonyadan söyleme. Ankara: İmge Kitabevi.

Vural, M. (2007). Siyaset felsefesi açısından muhafazakârlık. Ankara: Elis Yayınları.

Williamson, J. (2000). Reklamların dili- Reklamlarda anlam ve ideoloji (A. Fethi, Çev.). Ankara: Ütopya Yayınevi.

Yengin, H. (1996). Medyanın dili. İstanbul: Der Yayınevi. 
Yuval Davis, N. (2003). Cinsiyet ve millet (A.Bektaş, Çev.). İstanbul: İletişim Yayınları.

Willettis, D. (1992). Modern conservatism. UK, London: Penguin Books.

\section{Reklamlar}

Reklam 1 (2016, 14 Aralık). Yeni yıl anne. Erişim adresi: https://www.youtube.com/ watch?v=zHoxlqvkcwg.

Reklam 2 (2016, 28 Eylül). Evdeki yaramazlar. Erişim adresi: https://www.youtube.com/ watch?v=ssjcQ9LWwlo.

Reklam 3 (2016, 06 Mayıs). Ana menü. Erişim adresi: https://www.youtube.com/watch?v=pxfBBL7dvU.

Reklam 4 (2016, 06 Mayıs). Anneler biriktirir. Erişim adresi: https://www.youtube.com/ watch?v=YJ3Uq_9sfgc.

Reklam 5 (2015, 25 Nisan). X Anne olmak. Erişim adresi: https://www.youtube.com/ watch?v=EnC3wK2yDOc. 